\title{
EXPLAINING DIFFERENCES FOR SERBIA AND SLOVENIA IN MATHEMATICS ACHIEVEMENT IN FOURTH GRADE'
}

\begin{abstract}
This paper presents the findings that are parts of a larger international project studying the achievements in mathematics and science for students in primary and lower secondary education. Specifically, we focused on the study of differences in mathematics achievement for Serbian and Slovenian fourth-graders. The study used a sample of 7,861 fourth-grade students from Serbia $(N=3,736)$ and Slovenia $(N=4,125)$. The results showed that Serbian students had higher overall achievement and scored higher in both the number content and the knowing cognitive domains, whereas Slovenian students scored higher on the geometry content and the data content domains, also having a higher balance among achievements for both content and cognitive domains. It was also found that Slovenian students had higher self-confidence in learning mathematics. Because there were no other significant differences between Serbia and Slovenia with respect to two other contextual variables and the correlations among these three contextual variables, the explanations of the achievement differences were based upon the consideration of various aspects of curriculum, teaching practice, and teachers' professional development in Serbia and Slovenia. The paper raises the question of educational implications of these findings and the possible directions of improving the quality of mathematics teaching.
\end{abstract}

Keywords: elementary education, mathematics achievement, self-confidence in learning mathematics, TIMSS 2011.

$1 \quad$ This contribution resulted from the work of the first and the third authors on the project Improving the quality and accessibility of education in modernization processes in Serbia (No. 47008), financially supported by the Ministry of Education, Science and Technological Development of the Republic of Serbia (2011-2015). 
Djordje M. Kadijevich, Amalija Žakelj, Nikoleta Gutvajn

\title{
РАЗЛИКЕ У МАТЕМАТИЧКОМ ПОСТИНУЋУ УЧЕНИКА ЧЕТВРТОГ РАЗРЕДА ОСНОВНЕ ШКОЛЕ У СРБИЈИ И СЛОВЕНИЈИ
}

\begin{abstract}
Ancтракт Урадусу изложени налази који представљајудео обимног међународног пројекта проучавања постигнућа ученика основних школа у области математике и природних наука (TIMSS 2011). Конкретније, усмерили смо се на проучавање разлика у математичком постигнућу српских и словеначких ученика четвртог разреда основне школе. Истраживане је спроведено на узорку од 7,861 ученика четвртог разреда основне школе из Србије $(N=3,736)$ и Словеније $(N=4,125)$. Резултати истраживања показују да ученици из Србије имају виши ниво укупног постигнућа и више скорове у садржинском домену Број и когнитивном домену Знање, док ученици из Словеније имају више скорове у садржинским доменима Геометрија и Подаци, као и већи баланс између постигнућа у садржинским и когнитивним доменима. Такође, утврђено је да словеначки ученици имајувиши ниво самопоуздањ а у учењу математике у односу на ученике из Србије. С обзиром на то данисуутврђене значајније разлике и корелације по питану другихконтекстуалних варијабли у Србији и Словенији, објашњене разлика у математичком постигнућу ученика базирано је на разматрању различитих аспеката курикулума, наставне праксе и професионалног усавршавања наставника. У раду се поставља питање образовних импликација добијених налаза и могућих праваца унапређивања квалитета наставе математике.
\end{abstract}

Кључне речи: настава, математичко постигнуће, математичко самопоуздање, TIMSS 2011.

\section{РАЗНИЦА В УСПЕВАЕМОСТИ ПО МАТЕМАТИКЕ МЕЖДУ УЧЕНИКАМИ НАЧАЛЬНОЙ ШКОЛЫ В СЕРБИИ И СЛОВЕНИИ}

\begin{abstract}
Резюме
В работе приводятся некоторые результаты, полученные в рамках крупного международного проекта по изучению успеваемости учеников начальных школ в области математики и естественных наук (TIMSS 2011). В исследованиях мы ориентировались на изучение различий в успеваемости по математике у сербских и словенских учеников четвертого класса начальных школ. Исследование проведено на примере 7861 ученика четвертого класса начальной школы из Сербии ( $N=3736)$ и Словении $(N=4125)$. Результаты исследования показывают, что ученики из Сербии имеют более высокий уровень общего успеха и более высокие результаты по темам "Число" и "Знание", в то время как ученики из Словении имеют более высокие результаты по темем "Геометрия" и "Данные", а также большую сбалансированность между достижениями содержательного и когнитивного характера. Кроме того, было обнаружено, что словенские ученики имеют более высокий уровень уверенности
\end{abstract}


Explaining differences for Serbia and Slovenia in mathematics...

в себе при изучении математики, чем ученики из Сербии. Так как существенные различия по отношению к другим контекстуальным переменным не были обнаружены, объяснение различий в успеваемости по математике базируется на рассмотрении различных аспектов учебного плана и программы обучения, а также на учебной практике и профессиональной подготовке преподавателей. Поднимается вопрос образовательных последствий полученных результатов и возможных направлений актуализации качества преподавания математики.

Ключевые слова: обучение, успех в математике, математическая самоуверенность, TIMSS 2011.

\section{Introduction}

The International Association for the Evaluation of Educational Achievement (IEA) has conducted several international studies on mathematics and science achievements known as TIMSS studies (for more information about these studies see http://timss. bc.edu/). These studies have so far been realized in about 50 countries around the world and their outcomes have influenced the development and (re)design of mathematics and science education curricula in a number of countries (see, for example, Mullis et al., 2008a; Mullis et al., 2012a; Robitaille, Beaton \& Plomp, 2000). The TIMSS data also influenced a great number of secondary analyses (see, for example, Kadijevich, 2008; Robitaille \& Beaton, 2002; Vandecandelaere, Speybroeck, Vanlaar, De Fraine \& Van Damme, 2012; Wilkins, 2004).

In order to support secondary analyses of the TIMSS data, the TIMSS international databases available on http://timss.bc.edu/ contain values for many background indices regarding home, school, mathematics and science. These indices are very important variables because their values can help researchers explain the differences in students' obtained achievements within and across countries, helping educators to understand potential reasons for these differences and better manage their work on improving educational contexts and practices.

What kinds of mathematics achievement are provided by the TIMSS studies? Apart from the overall mathematics achievement, the TIMSS mathematical results are also given for different content domains as well as different cognitive domains. In TIMSS 2011 Grade 4 Study, there were three content domains and three cognitive domains (Mullis, Martin, Foy \& Arora, 2012).

Content domains were Number, Geometric shapes and measures, and Data display, or Number, Geometry, and Data, in short. These domains received 50\%, 35\%, and $15 \%$ of the assessment emphasis, respectively. In order to compare relative performance in these content domains with the overall mathematics achievement, IRT scaling was applied to place achievement in each of these three domains on the TIMSS mathematics scale for fourth grade. 
Cognitive domains were Knowing, Applying, and Reasoning, which, as Gutvajn, Džinović, \& Pavlović (2011) note, are related to cognitive domains found in the well-known Bloom's taxonomy. These domains received $40 \%, 40 \%$, and $20 \%$ of the assessment emphasis, respectively. In order to compare relative performance in these cognitive domains (requiring different skills at different difficulty levels) with the overall mathematics achievement, IRT scaling was also applied to place achievement in each of these three domains on the TIMSS mathematics scale for fourth grade.

What psychological constructs may in general be used to explain mathematics achievement? Research has strongly evidenced that students' attitudes toward mathematics are, in general, positively related to mathematics achievement (e.g., Hattie, 2009). Although the definition of the construct mathematics attitude varies in professional literature (Lin \& Huang, 2014), this construct typically include the dimension of self-concept, i.e. self-confidence in learning mathematics (e.g., Lim \& Chapman, 2013), which, when compared to other dimensions of mathematics attitude, may be the strongest predictor of mathematics achievement (Kadijevich, 2008). Other dimension of mathematics attitude typically found in the literature is that of liking or enjoyment of mathematics (Kadijevich, 2008; Lim \& Chapman, 2013). This dimension also positively correlates with mathematics achievement.

What TIMSS contextual variables concerning mathematics are related to the achievement in this subject? Although examine dimensions of mathematics attitude as 3-value ordinal variables, several official TIMSS reports evidence that these dimensions are positively related to mathematics achievement (e.g., Mullis et al., 2008; Mullis et al., 2012). In a secondary analysis of the TIMSS 2003 data for eight grade, realized for 137,346 students from thirty three countries that participated in this study, it was found that, for almost all of these countries, self-confidence in learning mathematics, liking mathematics, and usefulness of mathematics were positively related to mathematics achievement, where the relationship between this confidence and the achievement was the strongest one. It was also found that, for all countries, relations among these three dimensions were positive (Kadijevich, 2008).

Wilkins (2004) also evidenced positive relationship between self-confidence in learning mathematics and mathematics achievement at the student level (i.e. within country). At the country level (across countries), a negative relationship was found (the lower the confidence, the higher the achievement), which might be the result of stricter self-evaluations in countries that maintain high standards of and expectations for educational achievements.

It may be argued that, in general, TIMSS contextual variables are more based upon a consensus among TIMSS national representatives what to ask TIMSS participants than upon strong theoretical frameworks, but regarding mathematics attitude, this objection, as Kadijevich (2008) showed, is much less relevant.

What other math-related TIMSS contextual variable may be used to explain mathematics achievement? Apart from the relevance of attitudinal dimensions to mathematics achievement, the TIMSS 2011 Study evidenced the relevance of engagement in mathematics lessons as well. More precisely, it was students' opinions 
about their engagement in mathematics lessons that were positively related to their mathematics achievement (Mullis et al., 2012). Note that this variable (again examined as a 3-value ordinal variable) was not used in the TIMSS 2007 Study (see Mullis et al., 2008 , for math-related contextual variables applied in that study).

What were the main aims of the study? Bearing in mind that, as Mullis et al. (2012) show for the TIMSS 2011 Grade 4 Study, Serbia and Slovenia differed with respect to not only overall mathematics achievement, but also individual mathematics achievements regarding different content and cognitive domains, this study tried to explain these differences by using students' opinions concerning their confidence in learning mathematics, their liking to learn mathematics, and their engagement in mathematics lessons, as well as the relationships among the three. Furthermore, as the quality of knowledge should be defined not only in terms of achievement (e.g., the higher achievement, the higher the quality), but also, for example, in terms of the balance among achievements regarding different knowledge types (Miščević Kadijević, 2011) - which is an important aim of mathematics education (Kaino, 2013) - our analysis also examined the balance among achievements by content and cognitive domains (all expressed on a scale with 500 as its mean values). Our aim was thus also to compare these balances for Serbia and Slovenia and in the case of balance differences, to try to explain them by using differences between the two countries in these three contextual variables (confidence, liking and engagement) mentioned above and the relationships among them.

\section{Method}

Sample

This study used a sample of 7,861 students from Serbia $(3,736)$ and Slovenia $(4,125)$, who participated in the TIMSS 2011 Grade 4 Study. Although 8,871 four-graders from Serbia and Slovenia participated in this study, only students with complete data on all examined variables were included.

\section{Design and variables}

This study utilized factorial and correlative designs. Initially, ten variables were used. These variables, along with their measurements and reliabilities, are described in the following bulleted paragraphs.

- Achievement stands for students' overall mathematics achievement. It was determined as the average of the five plausible overall mathematics achievement estimators given in the TIMSS 2011 Grade 4 official files asgsrbm5.sav and asgsvnm5.sav for Serbia and Slovenia available at http://timss.bc.edu/timss2011/ (hereafter denoted as official TIMSS data). The reliability of this variable (Cronbach's alpha) was high (0.98 for Serbia and 0.97 for Slovenia). 
- Number denotes students' mathematics achievement in the number content domain. It was determined as the average of the five plausible number achievement estimators found in the official TIMSS data. The reliability of this variable was high $(0.97$ for Serbia and 0.96 for Slovenia).

- GeOMETRY refers to students' mathematics achievement in the geometry content domain. It was determined as the average of the five plausible geometry achievement estimators found in the official TIMSS data. The reliability of this variable was high (0.96 for Serbia and 0.95 for Slovenia).

- DATA denotes students' mathematics achievement in the data content domain. It was determined as the average of the five plausible data achievement estimators given in the official TIMSS data. The reliability of this variable was high ( 0.95 for Serbia and 0.94 for Slovenia).

- KNOWING stands for students' mathematics achievement in the knowing cognitive domain. It was determined as the average of the five plausible knowing achievement estimators found in the official TIMSS data. The reliability of this variable was high $(0.97$ for Serbia and 0.96 for Slovenia).

- ApPLYING refers to students' mathematics achievement in the applying cognitive domain. It was determined as the average of the five plausible applying achievement estimators found in the official TIMSS data. The reliability of this variable was high $(0.97$ for Serbia and 0.96 for Slovenia).

- REASONIng denotes students' mathematics achievement in the reasoning cognitive domain. It was determined as the average of the five plausible reasoning achievement estimators given in the official TIMSS data. The reliability of this variable was high (0.96 for Serbia and 0.95 for Slovenia).

- ConfIDENCE stands for student's self-confidence in learning mathematics. For each student, this confidence was equal to the average of his/her responses to the following seven statements: (1) I usually do well in mathematics*; (2) Mathematics is harder for me than for many of my classmates; (3) I am just not good at mathematics; (4) I learn things quickly in mathematics*; (5) I am good at working out difficult mathematics problems*; (6) My teacher tells me I am good at mathematics*; (7) Mathematics is harder for me than any other subject (Mullis et al, 2012; p. 337). Responses were officially coded by numbers 1-4 (1 for "Agree a lot", 2 for "Agree a little", 3 for "Disagree a little", and 4 for "Disagree a lot"), and, to attain a positively-oriented measure, scoring was reversed for statements denoted by ${ }^{\prime *}$. The reliability of this measure was very good ( 0.88 for Serbia and 0.84 for Slovenia).

- LIKING denotes student's liking to learn mathematics. For each student, this liking was equal to the average of his/her responses to the following five statements: (1) I enjoy learning mathematics*; (2) I wish I did not have to study mathematics; (3) Mathematics is boring; (4) I learn many interesting things in mathematics*; (5) I like mathematics* (Mullis et al, 2012; p. 331). Responses were officially coded by numbers 1-4 (1 for "Agree a lot", 2 for "Agree a little", 3 for "Disagree a little", and 4 for "Disagree a lot"), and, to attain a positively-oriented measure, scoring was reversed for statements denoted by '*'. The reliability of this measure was very good (0.89 for Serbia and 0.87 for Slovenia). ${ }^{2}$

2 When a two-factor solution was applied to all attitudinal statements $(7$ for CoNFIDENCE and 5 for LIKING), a clear factor structure was obtained in both Serbia and Slovenia; seven confidence statements loaded on the first factor, whereas the reimaging five liking statements loaded on the second factor. 
- Engagement refers to student's engagement in mathematics lessons. For each student, this engagement was equal to the average of his/her responses to the following five statements: (1) I know what my teacher expects me to do*; (2) I think of things not related to the lesson; (3) My teacher is easy to understand*; (4) I am interested in what my teacher says*; (5) My teacher gives me interesting things to do* (Mullis et al, 2012; p. 371). Responses were coded by numbers 1-4 (1 for "Agree a lot", 2 for "Agree a little", 3 for "Disagree a little", and 4 for "Disagree a lot"), and, to attain a positively-oriented measure, scoring was reversed for statements denoted by ${ }^{\prime * \prime}$. The reliability of this measure was low (0.69 for Serbia and 0.63 for Slovenia).

By examining also the balance among different achievements, two measures were added to the list of initial variables. These additional variables were CONTENT BALANCE and Cognitive BaLANCE.

- Content balance refers to the balance of student's achievements for the three content domains. For each student, this balance was equal to the minimum of the achievements for these content domains divided by the maximum of these three achievements. If, for one student, the values of variables NumBER, GEOMETRY and DATA were 500,480 , and 450 , the value of his/her CONTENT BALANCE was $450 / 500=0.9$ i.e. $90 \%$, which indicates somewhat balanced achievements.

- Cognitive balance denotes to the balance of student's achievements for the three cognitive domains. It was defined analogously to CONTENT BALANCE. For KNOWING $=500$, APPLYING $=400$ and REASONING $=420$, COGNITIVE BALANCE $=80 \%$ (from 400/500), which indicates unbalanced achievements.

By adding these two variables we focused on a numerical measure that could tell us to what extent the examined achievements were close to each other (cf. country profiles reported in Mullis et al., 2008, but not given in Mullis et al., 2012).

\section{Statistical analysis}

All statistical analysis (including the calculation of the Cronbach's alpha reliabilities), mostly realized in the SPSS program, used the official within-country sampling weights (Joncas, 2004). The applied weights were the rescaled values of the official totwgt variable so that, in each country, the sum of all rescaled values was equal to the sample size.

\section{Results}

Table 1 presents the means, standard deviations and reliabilities (Cronbach's alpha) for the measured variables by country. Several significant differences between and within countries were present at a 0.01 level. 
Djordje M. Kadijevich, Amalija Žakelj, Nikoleta Gutvajn

Table 1. Main data on twelve measured variables by country

\begin{tabular}{|c|c|c|}
\hline $\begin{array}{l}\text { Country } \\
\text { Variable }\end{array}$ & $\begin{array}{c}\text { Serbia } \\
(\mathrm{N}=3,736 ; 85.3 \% \\
\text { of tested students })\end{array}$ & $\begin{array}{c}\text { Slovenia } \\
(\mathrm{N}=4,125 ; 91.8 \% \\
\text { of tested students) }\end{array}$ \\
\hline 1. Achievement & $\mathbf{5 2 2} / 83$ / 0.98 & 515 / 65 / 0.97 \\
\hline \multicolumn{3}{|c|}{ Mathematics content domains } \\
\hline 2. Number & $\mathbf{5 3 5} \uparrow / 78 / 0.97$ & $505 \downarrow / 67 / 0.96$ \\
\hline 3. Geometry & $503 \downarrow / 89 / 0.96$ & $\mathbf{5 2 8} \uparrow / 60 / 0.95$ \\
\hline 4. Data & $510 \downarrow / 94 / 0.95$ & $535 \uparrow / 84 / 0.94$ \\
\hline 5. Content balance & 0.906 / 0.056 / NA* & 0.915 / 0.044 / NA \\
\hline \multicolumn{3}{|c|}{ Mathematics cognitive domains } \\
\hline 6. Knowing & $\mathbf{5 2 6 \uparrow / 7 8 / 0 . 9 7}$ & $512 \downarrow / 63 / 0.96$ \\
\hline 7. Applying & $517 \downarrow / 85 / 0.97$ & $516 \uparrow / 63 / 0.96$ \\
\hline 8. Reasoning & $521 / 95 / 0.96$ & $518 \uparrow / 71 / 0.95$ \\
\hline 9. Cognitive balance & $0.937 / 0.040$ / NA & 0.949 / 0.032 / NA \\
\hline \multicolumn{3}{|c|}{ Mathematics contextual variables } \\
\hline 10. Confidence & $3.16 / 0.68$ / 0.88 & 3.27 / 0.63 / 0.84 \\
\hline 11. Liking & 3.23 / 0.80 / 0.89 & $3.21 / 0.81 / 0.87$ \\
\hline 12. Engagement & 3.43 / 0.52 / 0.69 & $3.42 / 0.50 / 0.63$ \\
\hline
\end{tabular}

Significant differences between countries are given in bold (e.g., $522>515$ for overall mathematics achievement) For each country, arrows $(\uparrow, \downarrow)$ denote higher or lower particular achievements than the overall mathematics achievement (e.g., $535>522$ for Serbia).

* Not calculated.

Table 2 presents Pearson's correlations between achievement variables and balance variables on one side, and the three math-related contextual variables on the other. Although all correlations were significant at a 0.001 level, thirty correlations (of thirty-six in total) regarding LIKING and ENGAGEMENT were below 0.15 and may thus be practically considered as insignificant ones. What correlations did matter were those related to CONFIDENCE. Furthermore, by applying a 0.01 significance level, there were just two pairs of correlations with statistically different correlations for Serbia and Slovenia (0.52 vs. 0.46 for ReAsoning; 0.34 vs. 0.27 for Cognitive balAnCE). 
Explaining differences for Serbia and Slovenia in mathematics...

Table 2. Correlations between nine achievement variables and three contextual variables

\begin{tabular}{|l|l|l|l|}
\hline $\begin{array}{l}\text { Contextual variable } \\
\text { Achievement variable }\end{array}$ & Confidence & Liking & Engagement \\
\hline 1. Achievement & $0.50 / 0.47+$ & $0.13 / 0.13$ & $0.12 / 0.10$ \\
\hline \multicolumn{1}{|l|}{ Mathematics content domains } & $0.51 / 0.49$ & $0.14 / 0.16$ & $0.12 / 0.11$ \\
\hline 2. Number & $0.46 / 0.42 \#$ & $0.13 / 0.08$ & $0.12 / 0.07$ \\
\hline 3. Geometry & $0.47 / 0.45$ & $0.12 / 0.13$ & $0.11 / 0.11$ \\
\hline 4. Data & $0.31 / 0.28$ & $0.13 / 0.16$ & $0.17 / 0.13$ \\
\hline 5. Content balance & & & $0.11 / 0.10$ \\
\hline \multicolumn{1}{|l|}{ Mathematics cognitive domains } & $0.49 / 0.47$ & $0.13 / 0.13$ & $0.13 / 0.09$ \\
\hline 6. Knowing & $0.49 / 0.48$ & $0.13 / 0.14$ & $0.12 / 0.12$ \\
\hline 7. Applying & $\mathbf{0 . 5 2 / 0 . 4 6 *}$ & $0.14 / 0.13$ & $0.18 / 0.22$ \\
\hline 8. Reasoning & $\mathbf{0 . 3 4 / 0 . 2 7 *}$ & $0.17 / 0.18$ & \\
\hline 9. Cognitive balance & & & \\
\hline
\end{tabular}

+ Correlation for Serbia / Correlation for Slovenia.

$\# \mathrm{Z}=2.20, p=0.03$.

* Correlation different at a 0.001 level.

Table 3 reports Pearson's correlations among the three math-related contextual variables. All correlations were significant at a 0.001 level. Furthermore, by applying a 0.01 level of significance, there was no pair of correlations with statistically different correlations for Serbia and Slovenia.

Table 3. Correlations among three contextual variables

\begin{tabular}{|l|c|c|}
\hline Variable & $\mathbf{2}$ & $\mathbf{3}$ \\
\hline 1. Confidence & $0.51 / 0.53+$ & $0.47 / 0.49$ \\
\hline 2. Liking & & $0.64 / 0.61 \#$ \\
\hline 3. Engagement & & \\
\hline
\end{tabular}

+ Correlation for Serbia / Correlation for Slovenia.

$\# \mathrm{Z}=2.18, p=0.03$.

\section{Discussion}

Having in mind significant differences between Serbia and Slovenia, several important findings emerged from this study. These findings were the following:

- Serbia had more students with missing or incomplete data on the three contextual variables, and so their results were removed from the official files (14.7\% vs. $8.2 \%)$. 
- Serbian students had higher ACHIEVEment (522 vs. 515) and scored higher on Number (535 vs. 505) and KNOWING (526 vs. 512).

- Slovenian students scored higher on GeOMETRy (528 vs. 503) and Data (535 vs. 510$)$ and had higher Content Balance (0.915 vs. 0.906$)$ and Cognitive balanCE (0.949 vs. 0.937).

- $\quad$ Slovenian fourth-graders had higher ConfIDENCE (3.27 vs. 3.16).

- For Serbian students, there was stronger positive relationship between ReAsoning and Confidence (0.52 vs. 0.46).

- For Serbian students, there was stronger positive relationship between Cognitive balance and Confidence (0.34 vs. 0.27 ).

Some issues on missing data. We first focus on students removed from the official data files because their data on the three contextual variables were incomplete or missing. There were many such students in both Serbia $(643,14.7 \%$ of the original Serbian sample) and Slovenia (367, $8.2 \%$ of the original Slovenian sample). An additional analysis evidenced that the values of CONFIDENCE were not available for 388 Serbian students (8.9\%) and 198 Slovenian students (4.4\%). Having in mind the following numbers of excluded students by contextual variable (CONFIDENCE: 388 vs. 198; LIKING: 250 vs. 175; ENGAGEMENT: 199 vs. 132; the first number refers to Serbia), it might be that, contrary to Slovenian students, Serbian fourth graders would rather not respond to some items than gave responses that they did not know or were, in their view, not for the public. Note that ACHIEVEMENT of the excluded students was below the international average of 500 points (481 in Serbia and 491 in Slovenia).

Why did Serbian students have higher overall mathematics achievement? Serbian students had higher AcHievement but lower ConfiDenCE. To explain this discrepancy, several lines of reasoning may be pursued. A summary of three lines follows.

- At country level, there is a negative relationship between achievement and self-confidence (Wilkins, 2004), possibly influenced by standards of and expectations for educational achievements: the higher the standards, the higher the achievement but the lower the confidence (because students evaluate their abilities in a more rigorous way). This does not apply, however, because compared to Serbia, Slovenia has higher standards of and expectations for educational achievements.

- There may be a high level of anxiety of Serbian students regarding their mathematics learning (Radišić, Videnović \& Baucal, 2014). Higher mathanxiety usually goes with lower mathematics achievement (e.g., Cates \& Rhymer, 2003; OECD, 2013). Furthermore, higher math-anxiety results in lower self-confidence in learning mathematics (see OECD, 2010, for this negative relationship). It should be thus expected that Serbian students would have ACHIEVEMENT that is lower than Slovenian students. This did not happen, however.

- Higher Confidence of Slovenian students may be a sign of overestimation of their own abilities. Unskilled students may be unaware of their limited 
Explaining differences for Serbia and Slovenia in mathematics...

abilities for several reasons (for reasons, see, for example, Ehrlinger, Johnson, Banner, Dunning \& Kruger, 2008). Poor metacognitive abilities, for example, would rather block than develop student's educational potential. This overestimation may be a simple way to avoid facing failure in mathematics (Dweck, 2006), which would also rather block than develop student's educational potential. Because students with lower achievement and higher confidence generate a negative correlation between these two variables (that lowers a positive relationship between the two for other students), it may be clear why two positive relationships - between REASONING and CONFIDENCE, and between COGNITIVE BALANCE and CONFIDENCE - were stronger for Serbian students.

Why were there other differences in mathematics achievement for Serbian and Slovenian students? Because there were almost no significant differences between Serbia and Slovenia with respect to CoNFIDENCE, LIKING, and ENGAGEMENT as well as the relationships among these three math-related contextual variables, an explanation of these differences calls for the consideration of curriculum, teaching practice, and teachers' professional development in Serbia and Slovenia. There is a little doubt that the differences are the result of the type of mathematical tasks widely used in Serbian and Slovenian classrooms. Having in mind within country achievement differences in Serbia and Slovenia, it is clear that mathematical tasks in Serbian classrooms focus on numbers and operations with them and on learning (knowing) facts and procedures, whereas mathematical tasks in Slovenia rather focus on geometry and measurements, displaying data, and mathematical reasoning.

Slovenian curriculum is more focused on reasoning and problem solving, whereas Serbian curriculum is more focused on the cognitive domains of knowing and applying (Baucal, Radišić \& Stanković, 2014). Furthermore, while Serbian math curriculum for primary schools (available at www.zuov.gov.rs/novisajt2012/naslovna_ nastavni_planovi_programi.html), as being mostly unchanged for almost twenty-five years ${ }^{3}$, has not benefitted from the use of previous TIMSS and PISA results for Serbia, the situation in Slovenia is quite different as summarized below.

- The findings of IAEP 1991 and TIMSS 1995 studies evidenced that, before the introduction of new mathematics curriculum in Slovenia in 1998, Slovenian pupils were very skilful in doing calculations, whereas they were somewhat worse with the understanding of fundamental mathematical concepts. These studies also evidenced that when compared with pupils from other countries, they considerably lacked knowledge about data processing and problem knowledge (Cotič, Felda \& Hodnik Čadež, 2003). In this new curriculum, and its updated 2011 version, the main emphasis is on the use of mathematical knowledge and problem solving, and, as a result of this orientation, teachers use mathematical tasks not only to consolidate basic skills, but also to solve

3 Regarding the content of this curriculum introduced in 2006, just the volume of cube and rectangular cuboid was removed from its previous 1991 and 1996 versions. Other topics are more or less the same (in most cases even their formulations is the same). 
real life situations, and promote learning strategies in problem solving. Regarding data processing, this curriculum also systematically addresses it, from early to later grades, bearing in mind that, in general, data processing is an effective way to develop quantitative understanding and reasoning and improve problem knowledge connecting mathematics with other school subjects (Žakelj, 2010).

- On the basis of the results of Slovenian pupils in national and international assessments (Japelj Pavešić et al., 2005, Mullis et al., 2008), the modernization of curricula for elementary schools was made from 2008 to 2011. As regards the 2011 math curriculum, improvements were made with respect to both content and didactics. There are three themes in each grade (Logic and language, and Data processing introduced in 1998, and Mathematical problems and problems of life situations introduced in 2011), and, in each grade, the focus is on developing the techniques of reading text and interpreting it having in mind mathematical content and objectives (Žakelj et al., 2011).

According to the responses of the National Research Coordinators for the two countries, some TIMSS content topics were not included in the curriculum: for the number domain with 8 topics, 3 were not included in Serbia, whereas 4 were not included in Slovenia; for the geometry domain with 7 topics, 3 topics were not included in both Serbia and Slovenia; for the data domain, while all topics were included in Slovenia, none of them was included in Serbia (Mullis at al., 2012). Firstly, regarding content, it is clear that fourth-grade mathematics curriculum needs some improvements in both countries, especially in Serbia where the data domain is completely missing. Secondly, regarding didactics, it seems that, in general, tasks on geometry and measurements are better treated in Slovenia, whereas tasks on numbers are better treated in Serbia. The second conclusion is supported by Baucal et al. (2014), who found that while tasks on geometry and measurements were easier for Slovenian students, tasks in the number domain were easier for Serbian students.

Having in mind the content of the previous paragraph as well as the fact that, in general, teaching approaches differ in Serbia and Slovenia [e.g., instruction in Serbia not only heavily focus on memorizing facts, rules and procedures (69\% vs. $5 \%$ ), but also relies much more on frontal work with the whole class having direct teacher guidance (43\% vs. 13\%); see Exhibit 8.27 on p. 398 in Mullis et al., 2012], it may be understood not only why Serbian students scored higher in the knowing cognitive domain (average percent correct: $60 \%$ vs. $57 \%$ for all TIMSS students), but also why they scored higher in the number content domain (average percent correct: $54 \%$ vs. $47 \%$ for all TIMSS students), whereas Slovenian students scored higher in the geometry content domain (average percent correct: $57 \%$ vs. 50\% for all TIMSS students). (For given data, see Exhibit E.1 on p. 460 in Mullis et al., 2012.)

Tasks on data processing in Serbia and Slovenia. There is an emphasis on data processing tasks in Slovenia, which considerably improved Slovenian TIMSS achievement in the data content domain from 512 in 2007 to 532 in 2011 (or, in terms of average 
Explaining differences for Serbia and Slovenia in mathematics...

percent correct, from 64\% to 68\%). According to Žakelj et al. (2011), Slovenian students learn to collect, compile and present data and undertake their first empirical studies in the first three years, whereas in the next three years they learn to use digital tools to help them with these activities. Contrary to this successful Slovenian experience, data processing tasks are rarely solved by Serbian fourth graders because these tasks have been neglected in teacher professional development.

To illustrate the neglect of data processing tasks in Serbia, let us consider inservice development of elementary teachers in Serbia for teaching mathematics. For many teachers of elementary mathematics, this development has been arranged by Mathematical Society "Arhimedes" (see Kenderov et al., 2009, for more detail about this society and its numerous activities). When we focused on the period 2007-2010 (20 meetings with teachers were arranged), it was found that tasks on data and their presentations were only sporadically examined. Note that when some twenty years ago lower-secondary math teachers in Serbia were asked what areas should be removed from the curriculum, the topic of data was their first choice not only because teacher professional development had neglected this topic, but also because teachers found this topic to be not that mathematical (Kadijević, Marinković \& Brkić, 2004).

In-service development of primary mathematics teachers in Serbia and Slovenia. A continuously updated list of programs for in-service development (obligatory!) of Serbian teachers of mathematics, accepted by Serbian educational authorities, can be found at http://katalog2015.zuov.rs/ (follow the link математика). There were about forty programs in July 2014, and according to their descriptions, most of them were also designed for elementary teachers (dominant topics were geometry, visualization, and problem solving for above-average students; there was no program with focus on data processing). Each of these programs is usually arranged for 20-30 participants in a form comprising lectures and workshops. As some improvements of the classroom work on the basis of a particular program may only be attained when few hundreds of elementary teachers have been involved in it, these improvements may only happen in the long run. Note that programs for technology integration are not described in terms of possible gains regarding content, pedagogy and technology. An increasing importance of successful technology integration (see, for example, the Technology Principle in NCTM, 2000), calls for the use and implementation of a suitable framework for teacher professional development, such as TPCK - Technological Pedagogical Content Knowledge (Kadijevich, 2012; see also www.tpack.org).

Rules on further education and training for professionals in education in Slovenia (2004) are implemented in various forms of programs (Cencič, 2011). In-service training (that is optional) has primarily been arranged by the ministry responsible for education. A catalogue of available programs can be found at http://lim1.mss.edus.si/katis/default. aspx, and, in 2014/15, there were about 20 seminars for teachers of mathematics in primary and secondary education. Like in Serbia, this training involves rather a small numbers of teachers. There is also a catalogue of programs offered (free of charge) by the National Educational Institute of the Republic of Slovenia (www.zrss.si). This 
institute has been for 20 years carrying out the work of so-called study groups that focus on exchange of experience, system innovations, and changes in curriculum and examinations. In 2012/13 and 2013/14, primary mathematics topics were: updates of 2011 mathematics curriculum, crossing ten, problem solving, patterns, and assessment (two times of 4 hours of direct instruction was followed by a work in web classrooms). Because curriculum improvements in Slovenia are developed in schools (through action research involving teachers and curriculum planners), the preparation of curriculum documents and relevant didactic materials, and the introduction of innovations into practice take place simultaneously, which is according to Schollaert (2006), a good way to attain a successful curriculum update.

The balance of achievements by content domain and cognitive domain. The means of the two balance variables were above 0.90 (90\%), which is quite satisfactory. Slovenian students had higher both Content BaLANCE (0.915 vs. 0.906$)$ and Cognitive BALANCE (0.949 vs. 0.937). As the differences were just at a one-percent level (e.g., $0.949-0.937=0.012$ i.e. $1.2 \%)$, they do not have practical significance. However, there were more students is Serbia with CogNITIVE BALANCE below 0.90 (14.4\% vs. 6.4\% in Slovenia; weighted data were used). Regarding CONTENT BALANCE, there figures were as much as 39\% for Serbia vs. 33.9\% for Slovenia (again, weighted data were used), which strongly supports the conclusion that relating different content areas is not that strong in elementary mathematics teaching in Serbia and Slovenia. As these balance differences cannot be explained with empirical or educational differences reported in this article, further research may focus on the question of balance and main factors influencing it, possibly taking into account the issue of overestimating one's own abilities.

\section{Closing remarks}

Regarding curriculum and teacher education, elementary math teachers in Slovenia should also focus on the number content domain and the reasoning cognitive domain, whereas these teachers in Serbia should eventually deals with the topic of data processing as well as make tasks on geometry and measurement more accessible to students. Furthermore, in both Serbia and Slovenia, teachers should improve their classroom work to relate different content areas.

Students' attitudes toward mathematics are, in general, positively related to mathematics achievement (e.g., Hattie, 2009), and a critical dimension of these attitudes are students' self-confidence in learning mathematics (e.g., Kadijevich, 2008). In both Serbia and Slovenia, achievement variables were mostly related to CONFIDENCE. Although we do not know whether self-confidence in learning mathematics influences achievement or it is vice versa, a portion of learning tasks should be designed in a way that helps students build their self-confidence in learning mathematics. As mathematics teachers have a tendency to focus on one aspect of mathematical proficiency (e.g., knowing) hoping that other aspect(s) would develop more or less spontaneously (Kilpatrick \& Swafford, 2002), this way should require combining knowledge and 
skills from different content domains, or different cognitive domains. Relating different content domains can be attained by solving mathematical tasks in several ways. In doing that - of course, by using technology when appropriate - we would not only provoke and possible strengthen self-confidence in learning mathematics (cf. Eisenberg, 1991), but also promote a (more) balanced acquisition of different knowledge types, which is an important educational goal suggested by the results of the TIMSS studies.

\section{References:}

Baucal, A., Radišić, J. \& Stanković, D. (2014). Kurikulum iz matematike i postignuće četvrtaka na TIMSS 2011: Poređenje Srbije, Hrvatske i Slovenije. Knjiga rezimea XX naučni skup Empirijska istraživanja u psihologiji (str. 59-60). Beograd: Institut za psihologiju i Laboratorija za eksperimentalnu psihologiju Filozofskog fakulteta Univerziteta u Beogradu.

Cates, G. L. \& Rhymer, K. N. (2003). Examining the Relationship between Mathematics Anxiety and Mathematics Performance: An Instructional Hierarchy Perspective. Journal of Behavioral Education, Vol. 12, No.1, 23-34.

Cencič, M. (2011). Celostni razvoj pedagoških delavcev. V T. Vonta \& S. Sevkušić (ur.), Izzivi in usmeritve profesionalnega razvoja učiteljev (str. 29-38). Ljubljana: Pedagoški inštitut.

Cotič, M., Felda, D. \& Hodnik Čadež, T. (2005). Matematični del raziskave TIMSS 2003 za nižje razrede osnovne šole. Šolsko polje, Vol. 16, No.3-4, 145-156.

Dweck, C. S. (2006). Self-Theories: Their Role in Motivation, Personality, and Development. New York: Psychology Press.

Eisenberg, T. (1991). On Building Self-Confidence in Mathematics. Teaching Mathematics and its Applications, Vol. 10, No.4, 154-158.

Ehrlinger, J., Johnson, K., Banner, M., Dunning, D. \& Kruger, J. (2008). Why the Unskilled Are Unaware: Further Explorations of (absent) Self-Insight among the Incompetent. Organizational Behavior and Human Decision Processes, Vol. 105, No.1, 98-121.

Gutvajn, N., Džinović, V. i Pavlović, J. (2011). Od poznavanja činjenica ka znanju u primeni: kognitivni domeni u prirodnim naukama. U S. Gašić Pavišić i D. Stanković (ur.), TIMSS 2007 u Srbiji: rezultati međunarodnog istraživanja učenika 8. razreda osnovne škole iz matematike i prirodnih nauka (str. 211-229). Beograd: Institut za pedagoška istraživanja.

Hattie, J. (2009). Visible Learning: A Synthesis of over 800 Meta-Analyses Relating to Achievement. New York:Taylor \& Francis.

Japelj Pavešić, B., Brečko, B. N., Bezgovšek Vodušek, H., Čuček, M., Kozina, A., Lipovec, A., Magajna, Z., Perat, Z. \& Vidmar, M. (2005). Slovenija $v$ raziskavi TIMSS 2003: mednarodna raziskava trendov znanja matematike in naravoslovja: TIMSS 2003. Ljubljana: Pedagoški inštitut.

Joncas, M. (2004). TIMSS 2003 Sampling Weights and Participation Rates. In M. O. Martin, I. V. S. Mullis, \& S. J. Chrostowski (Eds.), TIMSS 2003 Technical Report (pp. 187-223). Chestnut Hill, MA:TIMSS \& PIRLS International Study Center, Boston College. Retrieved December 4, 2014 from the World Wide Web

http://timss.bc.edu/timss2003i/technicalD.html 
Kadijevich, Dj. (2008). TIMSS 2003: Relating Dimensions of Mathematics Attitude to Mathematics Achievement. Zbornik instituta za pedagoška istraživanja, Vol. 40, No. 2, 327-346. Retrieved December 4, 2014 from the World Wide Web www.doiserbia.nb.rs/img/doi/0579-6431/2008/0579-64310802327K.pdf

Kadijevich, Dj. (2012). TPCK Framework: Assessing Teachers' Knowledge and Designing Courses for their Professional Development. British Journal of Educational Technology, Vol. 43, No.1, 28-30.

Kadijević, Dj., Marinković, B. \& Brkić, P. (2004). How Successful Is Mathematics Education in Serbia According to the TIMSS 2003 Primary Results and What Should Be Done to Improve It? The Teaching of Mathematics, Vol.7, No.1, 53-60.

Kaino, L. M. (2013). Balancing of Cognitive Abilities: A Challenge to Quality in Mathematical Achievement. International Journal of Educational Sciences, Vol. 5, No. 3, 323-331. Retrieved December 4, 2014 from the World Wide Web www.krepublishers.com/02-Journals/IJES/IJES-05-0-000-13-Web/IJES-05-3-000-13-ABSTPDF/IJES-05-3-323-13-194-Kaino-L-M/IJES-05-3-323-13-194-Kaino-L-M-Tt.pdf

Kenderov, P., Rejali, A., Bartolini Bussi, M. G., Pandelieva, V., Richter, K., Maschietto, M., Kadijevich, Dj. \& Taylor, P. (2009). Challenges beyond the Classroom: Sources and Organizational Issues. In E. J. Barbeau \& P. Taylor (Eds.), Challenging Mathematics in and beyond the Classroom: The 16th ICMI Study (pp. 53-96). NewYork: Springer.

Kilpatrick, J. \& Swafford, J. (Eds.) (2002). Helping Children Learn Mathematics. Washington, DC: National Academies Press.

Lim, S. Z. \& Chapman, E. (2013). Development of a Short Form of the Attitudes toward Mathematics Inventory. Educational Studies in Mathematics, Vol. 82, No. 1, 145-164.

Lin, S. H., \& Huang, Y.C. (2014). Development and Application of a Chinese Version of the Short Attitudes toward Mathematics Inventory. International Journal of Science and Mathematics Education (in press).

Miščević Kadijević, G. (2011). Kooperativna nastava prirode i društva i kvalitet znanja učenika. Beograd: Učiteljski fakultet Univerziteta u Beogradu.

Mullis, I. V. S., Martin, M. O., Foy, P., Olson, J. F., Preuschoff, C., Erberber, E., Arora, A. \& Galia, J. (2008). TIMSS 2007 International Mathematics Report: Findings from IEA's Trends in International Mathematics and Science Study at the Fourth and Eighth Grades. Chestnut Hill, MA: TIMSS \& PIRLS International Study Center, Boston College. Retrieved December 4, 2014 from the World Wide Web http://timss.bc.edu/timss2007/mathreport.html

Mullis, I.V. S., Martin, M. O., Foy, P. \& Arora, A. (2012). TIMSS 2011 International Results in Mathematics. Chestnut Hill, MA: TIMSS \& PIRLS International Study Center, Boston College. Retrieved December 4, 2014 from the World Wide Web http://timss.bc.edu/timss2011/international-results-mathematics.html

Mullis, I. V. S., Martin, M. O., Minnich, C. A., Stanco, G. M., Arora, A., Centurino, V. A. S. \& Castle, C. E. (Eds.) (2012a). TIMSS 2011 Encyclopedia: Education Policy and Curriculum in Mathematics and Science (Vol. 1 and 2). Chestnut Hill, MA:TIMSS \& PIRLS International Study Center, Boston College.

Mullis, I. V. S., Martin, M. O., Olson, J. F., Berger, D. R., Milne, D. \& Stanco, G. M. (Eds.) (2008a). TIMSS 2007 Encyclopedia: A Guide to Mathematics and Science Education Around the World (Vol. 1 
Explaining differences for Serbia and Slovenia in mathematics...

and 2). Chestnut Hill, MA: TIMSS \& PIRLS International Study Center, Boston College.

National Council of Teachers of Mathematics (NCTM) (2000). Principles and Standards for School Mathematics. Reston, VA: NCTM. Retrieved December 4, 2014 from the World Wide Web www.nctm.org/standards

OECD (2013). PISA 2012 Results: Ready to Learn: Students'Engagement, Drive and Self-Beliefs (Vol. 3). Paris. Retrieved December 4, 2014 from the World Wide Web www.oecd.org/pisa/keyfindings/pisa-2012-results-volume-iii.htm

OECD (2010). Mathematics Teaching and Learning Strategies in PISA. Retrieved December 4, 2014 from the World Wide Web www.oecd.org/edu/school/programmeforinternationalstudentassessmentpisa/46052236.pdf

Pravilnik o nadaljnjem izobraževanju in usposabljanju strokovnih delavcev v vzgoji in izobraževanju (2004). Uradni list Republike Slovenije, 64 (junij 20049, 8088-8094).

Radišić, J., Videnović, M. \& Baucal, A. (2014). Math Anxiety: Contributing School and Individual Level Factors. European Journal of Psychology of Education (in press).

Robitaille, D. F. \& Beaton, A. E. (Eds.) (2002). Secondary Analysis of the TIMSS Data. Hingham, MA: Kluwer.

Robitaille, D. F., Beaton, A. E. \& Plomp, T. (Eds.) (2000). The Impact of TIMSS on the Teaching and Learning of Mathematics and Science. Vancouver: Pacific Educational Press.

Schollaert R. (2006). Pomen sprememb v izobraževanju. V S. Sentočnik i dr. (ur.), Vpeljevanje sprememb v šole: konceptualni vidik (str. 9-18). Ljubljana: Zavod Republike Slovenije za šolstvo.

Vandecandelaere, M., Speybroeck, S., Vanlaar, G., De Fraine, B. \& Van Damme, J. (2012). Learning Environment and Students' Mathematics Attitude. Studies in Educational Evaluation, Vol. 38, No. 3-4, 107-120.

Wilkins, J. L. M. (2004). Mathematics and Science Self-Concept: An International Investigation. The Journal of Experimental Education, Vol. 72, No.1, 331-346. Retrieved December 4, 2014 from the World Wide Web

http://www.soe.vt.edu/tandl/pdf/Wilkins/Publications_Wilkins_Mathematics_Science_ self_concept.pdf

Žakelj, A., Prinčič Röhler, A., Perat, Z., Lipovec, A., Vršič, V., Repovž, B., Senekovič, J. \& Bregar Umek, Z. (2011). Učni načrt. Program osnovna šola. Matematika. Ljubljana: Ministrstvo za šolstvo in šport, Zavod Republike Slovenije za šolstvo.

Žakelj, A. (2010). Data Processing and Statistics in the Slovenian Curriculum. In C. Reading (Ed.), Proceedings of the Eighth International Conference on Teaching Statistics, Ljubljana, July 1116, 2010. International Association for Statistics Education. 
Djordje M. Kadijevich, Amalija Žakelj, Nikoleta Gutvajn

\section{Подаци о ауторима}

Др Ђорђе Кадијевић је научни саветник Института за педагошка истраживања у Београду. E-mail: djkadijevic@ipi.ac.rs

Др Амалија Жакељ је водитељ Одељења за предметна подручја у Заводу Републике Словеније за школство, Љубљана, Словенија.

E-mail:amalija.Zakelj@zrss.si

Др Николета Гутвајн је научни сарадник Института за педагошка истраживања у Београду. E-mail: ngutvajn@ipi.ac.rs 